\title{
Behavior of Ilex paraguariensis St. Hilaire, 1822 to Meloidogyne incognita and $M$. paranaensis and their Influence on Development of Plantlets.
}

\author{
Débora Cristina Santiago $^{*}{ }^{*}$, Alaíde Aparecida Krzyzanowski ${ }^{2}$ and Martin Homechin ${ }^{1}$ \\ ${ }^{1}$ Agronomy Department, Paraná State University - UEL, CCA, CP 6001,CEP 86051-990, Londrina - PR, Brazil; \\ ${ }^{2}$ Agricultural Research Institute of Paraná - IAPAR, CP 481, CEP 86.047-902, Londrina - PR, Brazil.
}

\begin{abstract}
The influence of Meloidogyne incognita and M. paranaensis on the development of mate (Ilex paraguariensis ST. Hill) plantlets was assessed in greenhouse and laboratory. The experimental design was randomized. Every plot of each one of the 10 repetitions contained one mate plantlet, inoculated with 5,000 eggs of M. incognita (races 1, 2, 3 and 4) and M. paranaensis. After 120 days it was observed that mate was a reliable hostess to such nematodes and that they could finish their life cycle. Plant development was significantly modified by M. incognita, races 1 and 2. Dry and green matter weight of shoots changed according to treatment. No changes were observed in fresh root weight. The number of eggs per root was similar for M. incognita, races 1 and 2, and higher for the other treatments. The reproduction factor was above 1 for all treatments, indicating mate plants susceptibility to them.
\end{abstract}

Key words: tea, nematode, root-knot

\section{INTRODUCTION}

The mate-tree( Ilex paraguariensis St. Hill) has played an important role in the socio-economic development of Southern Brazil. For a certain period of time it was considered the second most important raw material for the Brazilian collection industry, following rubber-tree. In the State of Paraná, mate collection was an important economic activity for a long time. With the expansion of other crops, the importance of mate collection as a cash activity gradually decreased. The industrial sector which relied on mate as a raw material was seriously affected as well (Mazuchowski,1991).

During the early 80 's, the increase in area of annual crops, particularly soybean and wheat, destroyed most of the remaining native mate groves. Due to the still significant contribution of mate to small farmers' income, the government of Paraná set incentives for the production of mate plantlets. These plantlets are the usual material for propagation (Lozano \& Santos, 1991). The incentives led to the improvement of the old native mate groves as well as to the establishment of new cropping areas. As a result, in 1995 mate production in Southern Brazil rose to 675,000 tons (fresh weight ), Brazilian mate exports reached 26,000 tons, and 260,000 people in 131 municipalities were involved in fresh mate production (Hucker, 1995). The increase in the acreage under new mate groves has been followed by greater problems in plant protection, both in nurseries and field conditions. Important losses have been observed due to inadequate nursery practices, inappropriate transplanting and poor quality of plantlets (Lozano \& Santos, 1991). Contaminated plantlets are the main source of diseases, pests and nematodes in non-contaminated areas. The dissemination of root-knot nematodes is particularly important because of their wide range of hosts, causing economic losses for mate plant and intercrops as well. In addition, the infected soil is a permanent focus for further dissemination (Lozano \& Santos, 1991). In 1988, high incidence levels of $M$. javanica, $M$. hapla; $M$. incognita and Meloidogyne spp. were found on mate transplants in nurseries in the States of Paraná and Santa Catarina. Besides Meloidogyne 
sp, Helicotylenchus sp. was also found in Santa Catarina (Lozano and Santos, 1991). According to Tihohod (1993), the greatest losses occurred when susceptible plants were contaminated during the seedling stage. Adult plant may also produce significantly less and even become susceptible to other pathogens. Nematodes become more harmful when associated with other pathogens (Monteiro and Ferraz, 1992). Lozano and Santos (1991) observed small galls and egg masses in the root systems of mate plantlets previously infected with $M$. hapla, M. incognita and $M$. javanica. However, more knowledge is required about the damages caused by $M$. Incognita and $M$. paranaensis to mate, as well as these nematodes' life cycle and reproduction in roots (Klein et al., Mauch et al., 1991; Campos, 1978b; Lordello, 1981). This study was conducted in order to assess the pathogenicity and damages caused by Meloidogyne incognita (races 1, 2, 3 and 4) and M. paranaensis, to mate plantlets. This could improve the performance of old mate groves and increase the area with new ones.

\section{MATERIALS AND METHODS}

The experiments were conducted both in greenhouse and laboratory. Inoculum of Meloidogyne incognita and M. paranaensis were multiplied in the roots of tomato plants (Lycopersicon esculentum) cv. Rutgers and green pepper plants (Capsicum annum L. var. annum) cv. California Wonder. Hussey \& Barker technique (1973), adapted by Bonetti \& Ferraz (1981), was applied to extract nematode eggs. The inoculum were quantified and calibrated by using Peters' lamina under binocular microscopes. The randomised experimental design consisted of six treatments and ten repetitions. Each plot consisted of one plantlet with six to eight true leaves in the middle of a 1.5 litre plastic pot. The substrate was prepared with sandy soil, clay soil and rotten cow manure $(1: 1: 1)$, and treated with metil bromide $(150 \mathrm{ml} / \mathrm{m} 3)$. Sixty days after transplanting, 5,000 eggs of $M$. incognita (races $1,2,3,4)$ and $M$. paranaensis were inoculated in the rhizosphere of plantlets. The inoculum was distributed in two semicircle furrows $1-2 \mathrm{~cm}$ deep around the stem. The previously adjusted concentration of inoculum, containing both eggs and young kinds of $M$. incognita (races 1, 2, 3, and 4) and $M$. paranaensis, was then applied to the furrows with an automatic pipe. The influence of $M$. incognita (races 1, 2, 3,and 4) and $M$. paranaensis on plant height, as well as the dry and fresh weight of roots and shoots were assessed 120 days after inoculation. The average number of root eggs and the reproduction factor were also assessed. The number of eggs per root was determined by applying the Hussey \& Barker (1973) technique. Roots were cut in $5 \mathrm{~cm}$ pieces and ground in a blender with sodium hipocloride (NaOCL) at $0,5 \%$, for twenty seconds. The number of eggs was estimated by counting them in three samples of $1,0 \mathrm{ml}$ of the suspension, by means of a binocular microscope. The reproduction factor (Hadisoeganda \& Sasser, 1981) for each plot was calculated by dividing the number of eggs per root system by the inoculated population, on the $120^{\text {th }}$ day.

\section{RESULTS AND DISCUSSION}

M. incognita and $M$. paranaensis significantly reduced root and shoot fresh weight, shoot dry weight and plant height (Tables 1 and 2). As proposed by Tiholhod (1993), infected plants was likely to perform poorly in the field, as compared to those not hosting the nematodes. No significant differences among nematode races were found in root fresh weight, but infected roots weighted less than the control roots (Table 2). According to Bird (1970) and Viglierchio (1979), a lower development of infected roots might not be reflected in root weight, because gall weight could compensate for the reduction in root development. Therefore, root fresh weight was neither sufficient nor reliable to assess plant tolerance or susceptibility to phytonematodes. The number of eggs in roots was basically the same for $M$. incognita (races 1 and 2), and larger for plants with races 3 and 4 of $M$. incognita and $M$. paranaensis (Table 3). The reproduction factor in inoculated plantlets was always above 1, indicating mate susceptibility. Higher levels were found for $M$. incognita (races 3 and 4) and $M$. paranaensis (Table 4). 
Table 1. Effect of the inoculation of Meloydogine incognita (races 1, 2, 3, and 4) and M. paranaensis on shoot and root fresh weight and height of mate plantlets. Londrina, PR. 1998.

\begin{tabular}{|c|c|c|c|c|c|c|c|c|}
\hline \multirow{3}{*}{$\begin{array}{l}\text { Species } \\
\text { / } \\
\text { races }\end{array}$} & \multicolumn{4}{|l|}{ Shoots } & \multirow{2}{*}{\multicolumn{2}{|c|}{$\begin{array}{l}\text { Roots } \\
\text { Fresh weight (g) }\end{array}$}} & \multirow{2}{*}{\multicolumn{2}{|c|}{$\begin{array}{l}\text { Height } \\
(\mathrm{cm})\end{array}$}} \\
\hline & Dry weight (g) & & Fresh weight (g & & & & & \\
\hline & average $^{(* *)}$ & $\mathrm{CV}(\%)$ & average & $\mathrm{CV}(\%)$ & Average & $\mathrm{CV}(\%)$ & average & $\mathrm{CV}(\%)$ \\
\hline M. incognita $\mathrm{r} 1$ & $1,33 \pm 0,30 \mathrm{a}$ & 18,32 & $4,00 \pm 0,54 a$ & 38,16 & $4,87 \pm 1,34 \mathrm{a}$ & 48,62 & $20,59 \pm 1,39 a$ & 22,14 \\
\hline Control & $15,73 \pm 1,54 b$ & & $19,40 \pm 3,96 \mathrm{~b}$ & & $7,13 \pm 2,24 a$ & & $26,55 \pm 4,45 b$ & \\
\hline M. incognita $\mathrm{r} 2$ & $2,21 \pm 0,48 \mathrm{a}$ & 15,93 & $7,38 \pm 1,41 \mathrm{a}$ & 25,24 & $6,93 \pm 1,67 a$ & 28,06 & $19,15 \pm 1,23 \mathrm{a}$ & 24,71 \\
\hline Control & $11,62 \pm 0,15 b$ & & $25,79 \pm 3,47 b$ & & $7,68 \pm 0,76 a$ & & $31,00 \pm 5,40 b$ & \\
\hline M. incognita r 3 & $4,86 \pm 0,99 a$ & 22,50 & $9,51 \pm 3,28 \mathrm{a}$ & 31,46 & $11,78 \pm 1,86 a$ & 46,80 & $20,15 \pm 1,65 \mathrm{a}$ & 23,39 \\
\hline Control & $11,28 \pm 0,42 b$ & & $25,49 \pm 3,67 b$ & & $12,09 \pm 4,64 a$ & & $24,60 \pm 4,38 \mathrm{a}$ & \\
\hline M. incognita $\mathrm{r} 4$ & $6,95 \pm 0,58 \mathrm{a}$ & 10,60 & $18,47 \pm 3,31 \mathrm{a}$ & 24,53 & $11,89 \pm 1,89 a$ & 37,72 & $18,56 \pm 1,65 a$ & 16,30 \\
\hline Control & $9,18 \pm 0,49 b$ & & $24,82 \pm 3,57 b$ & & $15,37 \pm 3,65 a$ & & $19,57 \pm 2,30 a$ & \\
\hline M. paranaensis & $4,67 \pm 0,36 a$ & 11,11 & $4,14 \pm 0,68 \mathrm{a}$ & 45,32 & $13,44 \pm 0,63 a$ & 48,89 & $21,88 \pm 4,49 a$ & 47,83 \\
\hline Control & $10,69 \pm 0,36 b$ & & $12,88 \pm 3,38 b$ & & $13,65 \pm 1,43 a$ & & $23,25 \pm 8,68 \mathrm{a}$ & \\
\hline
\end{tabular}

${ }^{(* *)}$ Averages, followed by different letters, are statistically different at $5 \%$ Tukey.

Table 2. Fresh and dry shoot weight, root fresh weight and height of mate plantlets inoculated with Meloidogyne incognita and M. paranaensis as percent of the control. Londrina, PR. 1998.

\begin{tabular}{cllll}
\hline \multirow{2}{*}{$\begin{array}{c}\text { Species } \\
\text { races }\end{array}$} & \multicolumn{3}{c}{ Shoots } & Roots \\
\cline { 2 - 5 } & $\begin{array}{l}\text { Dry } \\
\text { weight }\end{array}$ & $\begin{array}{l}\text { Fresh } \\
\text { weight }\end{array}$ & $\begin{array}{l}\text { Fresh } \\
\text { weight }\end{array}$ & Height \\
\hline M. incognita $\mathrm{r} 1$ & 91,55 & 79,38 & 31,56 & 22,79 \\
M. incognita $\mathrm{r} 2$ & 80,98 & 71,38 & 9,77 & 38,23 \\
M. incognita $\mathrm{r} 3$ & 57,00 & 62,29 & 2,56 & 18,09 \\
M. incognita $\mathrm{r} 4$ & 24,29 & 25,83 & 22,64 & 5,16 \\
M.paranaensis & 56,31 & 68,17 & 1,54 & 5,89 \\
\hline
\end{tabular}

Table 3. Average number of eggs in the roots of mate plantlets inoculated with $M$. incognita (races1, 2, 3, and 4) and M. paranaensis. Londrina, PR. 1998.

\begin{tabular}{lll}
\hline Specie/ & eggs/ & eggs/ \\
races & $1 \mathrm{~mL}$ & $200 \mathrm{~mL}$ \\
\hline M. incognita $\mathrm{r} 1$ & 77,70 & 15540,00 \\
\hline M. incognita $\mathrm{r} 2$ & 78,50 & 15700,00 \\
\hline M. incognita $\mathrm{r} 3$ & 314,70 & 62940,00 \\
\hline M. incognita $\mathrm{r} 4$ & 284,78 & 56955,56 \\
\hline M.paranaensis & 279,89 & 55977,78 \\
\hline
\end{tabular}

Table 4. Reproduction factor for Meloidogyne incognita (races 1, 2, 3, and 4) and M. paranaensis, in the roots of mate plantlets in greenhouse. Londrina, PR. 1998.

\begin{tabular}{llll}
\hline $\begin{array}{l}\text { Species/ } \\
\text { races }\end{array}$ & $\begin{array}{l}\text { Initial } \\
\text { population }\end{array}$ & $\begin{array}{l}\text { Final } \\
\text { population }\end{array}$ & $\begin{array}{l}\text { Reproduc. } \\
\text { factor }\end{array}$ \\
\hline$M$. incognita $\mathrm{r} 1$ & 5000,00 & 15540,00 & 3,11 \\
\hline M. incognita $\mathrm{r} 2$ & 5000,00 & 15700,00 & 3,14 \\
\hline M. incognita $\mathrm{r} 3$ & 5000,00 & 62940,00 & 12,59 \\
\hline M. incognita $\mathrm{r} 4$ & 5000,00 & 56955,00 & 11,39 \\
\hline M.paranaensis & 5000,00 & 55977,78 & 11,20 \\
\hline
\end{tabular}

\section{RESUMO}

A influência de Meloidogyne incognita e $M$ paranaensis no desenvolvimento de mudas de erva-mate, foi avaliada em casa-de-vegetação e laboratório. $\mathrm{O}$ delineamento experimental foi inteiramente casualizado, com 10 repetições, sendo cada parcela formada de 1 plântula de ervamate/vaso, inoculada com 5000 ovos de $M$. incognita raças 1, 2, 3, 4 e M. paranaensis. Aos 120 dias, observou-se que a erva-mate, além de boa hospedeira destes nematóides, permitiu-lhes completar seu ciclo vital. O desenvolvimento das plantas foi significativamente afetado pelas raças 1 e 2 de $M$. incognita.; os pesos de matéria seca e fresca da parte aérea sofreram alterações conforme o tratamento. Não houve alteração no peso fresco de raízes e o número de ovos por raízes foi semelhante para as raças 1 e 2 de $M$. incognita, sendo, porém, mais elevado nos demais tratamentos. O fator de reprodução foi superior a $1 \mathrm{em}$ todos os tratamentos, indicando a susceptibilidade da erva-mate a estes agentes.

\section{REFERENCES}

Bird, A. F. (1970), The effect of $\mathrm{N}$ deficiency on the growth of Meloidogyne javanica at different populational levels. Nematologica, 16, 13 -21.

Bonetti, J. I. S.; Ferraz, S. (1981), Modificação do método de Hussey \& Barker para extração de ovos de Meloidogyne exigua de cafeeiro. Fitopat. Brasileira, 6, 553. 
Campos, V. P. (1987b), Caracterização de raças de Meloidogyne incognita e estudos sobre níveis de inóculo de $M$. javanica e $M$. incognita em batata. Nematol. Brasileira, II, 249-259.

Ferraz, L.C.B. (1986), Observações histopatológicas em raízes de Eucalyptus citriodora HK. e Pinus caribacea MOR. parasitadas por nematóide das galhas. Fitopat. Brasileira, 9:1, 91-96.

Ferraz, L.C.B. \& Lordello, L.G. (1982), Suscetibilidade e danos causados as espécies de Eucalyptus e Pinus por nematóides das galhas no Estado de São Paulo. Rev. de Agricultura. Piracicaba. SP. 57: 1-2, 67-73.

Ferraz. L.C.B.; Lordello, L.G.; Monteiro, A.R. (1984), Nematóides associados a espécies de Eucalyptus, Pinus $e$ outras essências florestais cultivadas. Rev. de Agricultura, Piracicaba, SP, 59:1, 59-68.

Ferreira, F.A. (1989), Patologia Florestal. Principais Doenças Florestais no Brasil. Viçosa, 570 p.

Hücker, N. G. De A. (1995), Erva-mate. Deral, Curitiba.

Hussey, R. S. \& Barker, K. R. (1973), A comparison of methods for collecting inocula of Meloidogyne spp. including a new technique. Plant Dis. Reptr, Washington, 57:2, 1025-1028.

Klein, A.L.; Ferraz, L.C.C.B., Oliveira, J.C. (1984), Comportamento de diferentes maracujazeiros em relaçâo ao nematóide formador de galhas. Pesq. Agropec. bras., Brasília, 19:2, 207-209.

Lordello, L.G. (1976), Nematóide dizima sementeiras de caxeta. Rev. de Agricultura. Piracicaba, SP, 51:34, 203-205.

Lordello, L.G. (1977), Um nematóide nocivo ao ipêroxo. Rev. de Agricultura, Piracicaba, SP. 52:4, 265.

Lordello, L.G. (1981), Nematóide das plantas cultivadas. 6 ed.. São paulo, Nobel, 314p.

Lordello, L.G. (1987), Doença de eucalipto causada por um nematóide. Rev. de Agricultura. SP, 42:1, 11-13.

Lordello, L.G. \& Kanazawa, P.S. (1967), Nematóide nocivo ao quiri. Rev. de Agricultura, SP, 42: 3, 107108.

Lordello, L.G. \& Veiga, A.S. (1983), Nematóides em seringueira. Rev. de Agricultura, SP. 58:3, 203-207.

Lozano, L.A.L.; Santos, B.B. (1991), Ocorrência de nematóides do gênero Meloidogyne em mudas de erva-mate no Estado do Paraná. Rev. de Agricultura, Piracicaba, 66: 2, 203-205.
Mauch, C. H.; Mauch, N.; Finardi, N. L. (1991), Reações de pessegueiros e de ameixeira ao nematóide das galhas Meloidogyne incognita. Nemat. Bras. v. 15 .

Mazuchowski, J.Z. (1991), Manual da erva-mate. Empresa Paranaense de Assistência Técnica e Extensão Rural, Curitiba, 104p.

Mendes, B.V. \& Cardoso. C.O.N. (1978), Algumas observações histopatológicas de raízes de ipê roxo parasitadas por, M.. arenaria. Summa Phytopathologica, 4: 49-54.

Mendes, S. \& Ferraz, M. de L. (1992), Os nematóides das galhas. Informe agropecuário, Belo Horizonte. 16: $172,37-42$.

Monteiro, A. R. \& Ferraz, L. C. B. (1992), Curso de nematóides parasitas de plantas. USP-ESALQ.

Ponte, J. J. Da; Lemos, W. V. \& Ponte, M. A. da. (1977), Implicações da meloidoginose sobre o crescimento e a produção de tomateiro. IN: Reunião da Sociedade Brasileira de Nematologia, 2, Piracicaba, 1977. Trabalhos apresentados... Piracicaba, Sociedade Brasileira de Nematologia, p.61-64.

Hadisoeganda, W.W. \& Sasser, J.N. (1981), Resistance of tomato, bean, southern pea and garden pea cultivars to root-knot nematodes basead on host suitability. Plant Disease, St. Paul, 66:145-50.

Santos, B.B. (1988a ), Nematóides do gênero Meloidogyne Goeldi e algumas plantas hospedeiras do Estado do Paraná. Rev. de Agricultura, Piracicaba, 63: 1, p. 37-43.

Santos, B.B. (1988b), Notas sobre alguns nematóides parasitas de plantas. Rev. de Agricultura, Piracicaba, 63: 1, 83-84.

Tihohod, O. (1993), Nematologia Agrícola Aplicada. Jaboticabal, FUNEP, 372 pp.

Vigliercho, D. R. (1979), Response of Pinus ponderosa seedlings to stvlet-bearing nematodes. J. Nematol., 11: $3,77-387$.
Received: May 25, 1998; Revised: June 18, 1999; Accepted: October 29, 1999. 